\title{
DETERMINANTS OF TECHNOLOGICAL INNOVATIONS IN HEALTH TOURISM ENTERPRISES
}

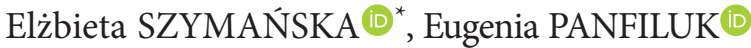 \\ Faculty of Engineering Management, Bialystok University of Technology; 45A Wiejska Street, \\ 15-351 Bialystok, Poland
}

Received 25 August 2019; accepted 08 November 2019

\begin{abstract}
The research problem is the implementation of technological innovations in health tourism services. The main purpose of the paper is diagnosing determinants of technological innovativeness of enterprises that provide health tourism services. Two detailed objectives were laid down - specifically, an indication of these determinants in respect of the range and type of a technological innovation. The methods applied in the research are: Delphi method, comparative analysis, the range method and the standardised interview method. In order to indicate determinants the following research techniques were used: Kruskal - Wallis test, factor analysis, analysis of medium-rank test, Spearman's rank order correlation test. The primary result is diagnosing determinants affecting technological innovativeness of the subjects under study which are: quality of endogenous human capital of the surveyed entities and inflow of external information. The research is of ground-breaking nature since until now, technological innovations in health tourism have not been described in economy literature. The results have an impact on the development of economics and management sciences, contributing to the development of innovation theory and enterprise management. Moreover, the results potentially contribute to the practical aspect by means of their application by practitioners - organisers of health tourism.
\end{abstract}

Keywords: some innovations, radical innovations, technology, tourism, health tourism.

JEL Classification: I15, L83, O30.

\section{Introduction}

Health tourism innovativeness provides a response to the rapidly increasing public demand for living a long life, being in good health, retaining beauty, and staying in good shape. Growing life expectancy and the increase in customers' leisure budget stimulate the demand for services improving or preserving health.

The research problem discussed in this paper is technological innovation in health tourism. Joseph Schumpeter defined innovation as "the introduction of new products into production or the improvement of existing products, the introduction of a new or improved production technology, the use of a new sales or purchase method, the opening of a new market of both sales or distribution of output and supply, the use of new raw materials or intermediate products, the introduction of changes in the organization of production" (Schumpeter, 1960). In the Manual published by the Organization for Economic Cooperation and Development (OECD, 2005), innovation can be related to a product, process, organisation or marketing. Technological innovations, as part of process innovations, are defined as new processes or methods of production (Ciburiene, 2009). In the research on services, two types of technological innovations are distinguished, i.e. the use of new technologies (machinery and equipment) and the application of new, specialised software.

The main objective of the paper is to indicate main factors (determinants) of technological innovations in health tourism enterprises, with particular consideration given to radical innovations. Radical innovations, defined in the research as innovations with a worldwide range, are innovations of a unique character. Two detailed objectives were laid down - specifically, an indication of these determinants in respect of the range of an implemented innovation and in respect of the type of the implemented innovation. In respect of the range, innovations with a worldwide range (radical ones) and those with a national or regional range are distinguished (Szymańska, 2009, 2013).

*Corresponding author. E-mail: e.szymanska@pb.edu.pl 
In addition, the following research questions were posed:

P1 - What is the level of technological innovativeness in health tourism enterprises?

P2 - What factors of key significance (determinants) as well as supportive and complementary significance affect the implementation of technological innovations in the investigated enterprises?

A determinant is defined as a factor or a group of factors (independent variables) which affect(s) to the greatest extent a dependent variable (Janasz \& Kozioł, 2007); in the present case, such a variable is the innovativeness of the investigated entities.

Health tourism industry in Poland, one of the most dynamically developing service sectors, was chosen as the research area. Health tourism can be defined as "the practice of travelling abroad to receive medical care in order to enhance health or cure a disease" (Chang et al., 2014). The scope of this type of tourism includes health resort, spa \& wellness, medical treatment and aesthetic medicine services provided to tourists (Szymańska, 2017; Panfiluk, 2016).

The Authors used the Delphi method, a method of comparative analysis and the standardised interview method. In the research, the dependent variable was a technological innovation, whereas 53 independent variables included in the questionnaire used for the standardised interview were determined on the basis of source literature.

\section{Literature review}

\subsection{Technological innovations in the economic science literature}

Schumpeter's point of view was continued by Rosenberg (Rosenberg et al., 1994), Drucker (2004) and Gault (2010). His idea provided a basis for the OECD publications (2005), according to which innovation involves the transformation of an idea into a saleable product or service, a new or improved production or distribution process, or a new method of social service. Innovation is the drive for competitiveness (Banyte \& Salickaite, 2008).

These days, economic activity and its internationalised dimension are strongly affected by such factors as knowledge and information. It was the result of progress in Information and Communications Technology (ICT) which fostered fast data processing into information and knowledge. The effect is the stimulation of innovation and the development of intellectual capital and entrepreneurship (Zorska, 2007). The most interesting issue for technological innovativeness is innovation policy (Teece, 1997; Grupp \& Mogee, 2004; Balezentis \& Balkiene, 2014; Nazarko, 2016; Halicka, 2016). The main area of the research on innovativeness is innovative activity of production enterprises (Tuominen et al., 2004; Perunovic \& Christiansen, 2005 ) with special consideration for technological progress, $\mathrm{R} \& \mathrm{D}$ expenditure and its roles in the innovation process (Webber, 1996; Urban \& Czerska, 2016). A critical research area is innovativeness in the globalisation process as well as knowledge-based economy (Rycroft, 2003; Ejdys et al., 2015).

Literature offers numerous publications on technological innovations. For instance, in the EBSCO base, upon entering this notion there appeared as many as 1,423,293 records, namely publications that include the expression "technological innovations" in the title, abstract or among keywords. Most of them refer to enterprises. Among other things, Flynn's publication was used as a model. Flynn (Flynn, 2013, p. 6), distinguished 3 groups of technological innovations: radical, incremental and disruptive. The issue of implementing technological innovations in small and medium enterprises were undertaken by Barhoum and Djaouahdou (2017) or Chin-miel Su (2018), to mention just a few. However, publications referring to health tourism and innovations in tourism sector have the greatest significance for the conducted research.

\subsection{Health tourism}

Health tourism develops in a dynamic way and there are various publications on this subject matter. However, most of them are descriptive and have a reporting character. The term "health" means "a state of complete physical, mental and social well-being, ensuring a socially productive life in social, economic and mental terms, also in the spiritual dimension" (World Health Organization, 2017). Customers of health tourism services comprise not only of those suffering from specific diseases, but also persons with physical conditions who want to change their lives, improve their current health condition or experience new challenges. According to Amodeo research (2010), health tourism has already developed in more than 35 countries.

An in-depth analysis and a classification of publications about medical tourism written by Chuang et al. (2014) prove a lack of studies in the field of medical tourism innovativeness (Chuang et al., 2014). In their opinion, there are publications offering concepts and insights that should be included in such studies. They include some new ideas which are worth mentioning: a model of medical tourism demand and supply (Heung et al., 2010) and a model of medical tourism supply chain Lee \& Fernando, 2015; Heung et al., 2010). Concepts of competitiveness of medical tourism destinations (Cormany \& Baloglu, 2010) reaction to the globalisation process (Lunt \& Carrera, 2010; Morgan, 2010; Hazarika, 2010) claims that travelling for health purposes is caused by the availability of cheaper and alternative procedures conducted outside the country of residence.

\subsection{Innovations in health tourism}

The issue of innovation in tourism is a new research problem. This topic was discussed for the first time during the international forum organized by the OECD (2006). The outcome of the forum was published papers of ten authors. They described various aspects of the phenomenon 
of tourism innovativeness. In their research, Hall and Williams (2008) discovered that in tourism there exists a strong relationship between innovations in enterprises and their destinations. A lot of research on innovativeness based on such indicators as R\&D expenditures, number of patents granted and the number of new products can underestimate the real effects of innovation processes in tourism (Sundbo et al., 2007). Academic literature provides two most common types of studies: reviews offering conceptual insights into the phenomenon and case studies showing particular concepts pertinent to innovation. In her overview of innovation in tourism research, Hjalager $(2009,2002)$ discusses the main topics which still deserve further elaboration in the research agenda. Being a pioneer in research on tourism innovativeness, Hjalager enumerated some major areas related to the issue of innovation in tourism (Hjalager, 2002):

- categories of innovation;

- determinants and driving forces;

- search processes and knowledge sources of innovation;

- extent and effects of innovative activities;

- implications and impacts of innovations;

- innovation policies.

In his publication, Stepaniuk (2012) concludes that, it is important to modernise the tourism base as well as marketing methods designed to win new customers, using new computer-assisted techniques before new tourism offers are introduced. A similar subject matter was the subject of research conducted by Palos-Sanchez et al. (2018), who studied marketing innovations in tourism based on user's opinions. As a result, they adopted a new outlook on the issue, as exemplified by geolocation and geomarketing.

\section{Related work - indication of research gap}

The starting point of the conducted research was initiated with two publications by Szymańska. The first of them concerned research on innovativeness among tourism enterprises in Poland, where, apart from product-based, organizational and marketing innovations, also technological innovations were taken into consideration (Szymańska, 2009, 2013). On the other hand, a publication devoted to technological innovations in travel agencies can be considered as a sign of deeper research in this area (Hjalager, 2010). The most useful were studies conducted in a parallel manner within the same project. The most significant ones included research by Szymańska et al. (2017) on general indications and principles of studying innovation in health tourism, as well as an article by Szymańska on systems of innovativeness in health tourism and affecting factors (Szymańska et al., 2017). Literature review conducted on 10.11.2018 r. in EBSCO, Web of Science and Scopus databases proved that technological innovations in health tourism did not constitute at that time the subject of separate research (the review made in each of these three databases did not result in discrepancies, which means that it equalled 0 ). Thus, the authors based their elaborations on research indicated in the above publications on innovations in health tourism.

To sum up, it needs to be highlighted that researchers do not pay much attention to technological innovations in tourism, particularly in health tourism. The several publications which can serve as a reference point include attempts to trace back research which was taken as a subject matter by the OECD (2006), Stepaniuk (2012), Dziedzic (2011), Szymańska $(2009,2013)$, that is research on technological innovations in the tourism sector.

In conclusion, it should be said that to date the issue of technological innovations in health tourism has not been scientifically explored. The signalled shortages in theory and practice justify the purposefulness of findings both in the theoretical dimension, associated with the need to explore the subject matter more deeply, as well as the practical sense.

\section{Conceptual framework and development of hypothesis}

The research conducted by the authors was carried out at several stages, using adequate methods, as illustrated by Figure 1.

The first stage of the research procedure involved determining the population (providers of health tourism services) as well as defining innovations and their types. It was conducted on the basis of the scientific literature on innovations, in particular the OECD papers (OECD, 2005, 2008) and expert studies with the Delphi method. Based on recommendations included in the Oslo Manuals (OECD, 2005, 2008), the research extended over a threeyear period (from 2013 to 2015) were conducted from 2015 to 2017. Two hypotheses were verified:

H1: The main determinant of introducing radical technological innovations in enterprises that provide health tourism services are customers' (tourists') expectations (needs).

$\mathrm{H} 2$ : It is assumed that the determinants of technological innovativeness of the investigated enterprises are the same, irrespective of the range of innovation.

The hypotheses were verified in the course of qualitative research with a division into four basic groups of entities providing health tourism services (Andreeva, 2014), them being: spa \& wellness, health resort, aesthetic medicine and medical treatments.

\section{Methodology}

\subsection{Data collection and analysis}

In collecting research material, the Delphi method and a method of diagnostic survey were used. The Delphi method is applied in qualitative research by e.g. Dalkey and Helmer (1963) as well as Grisham (2009). Repeatedly conducted research, used in the Delphi method, allows for reducing the impact of such group interactions as domination of any of the experts or group pressure during 


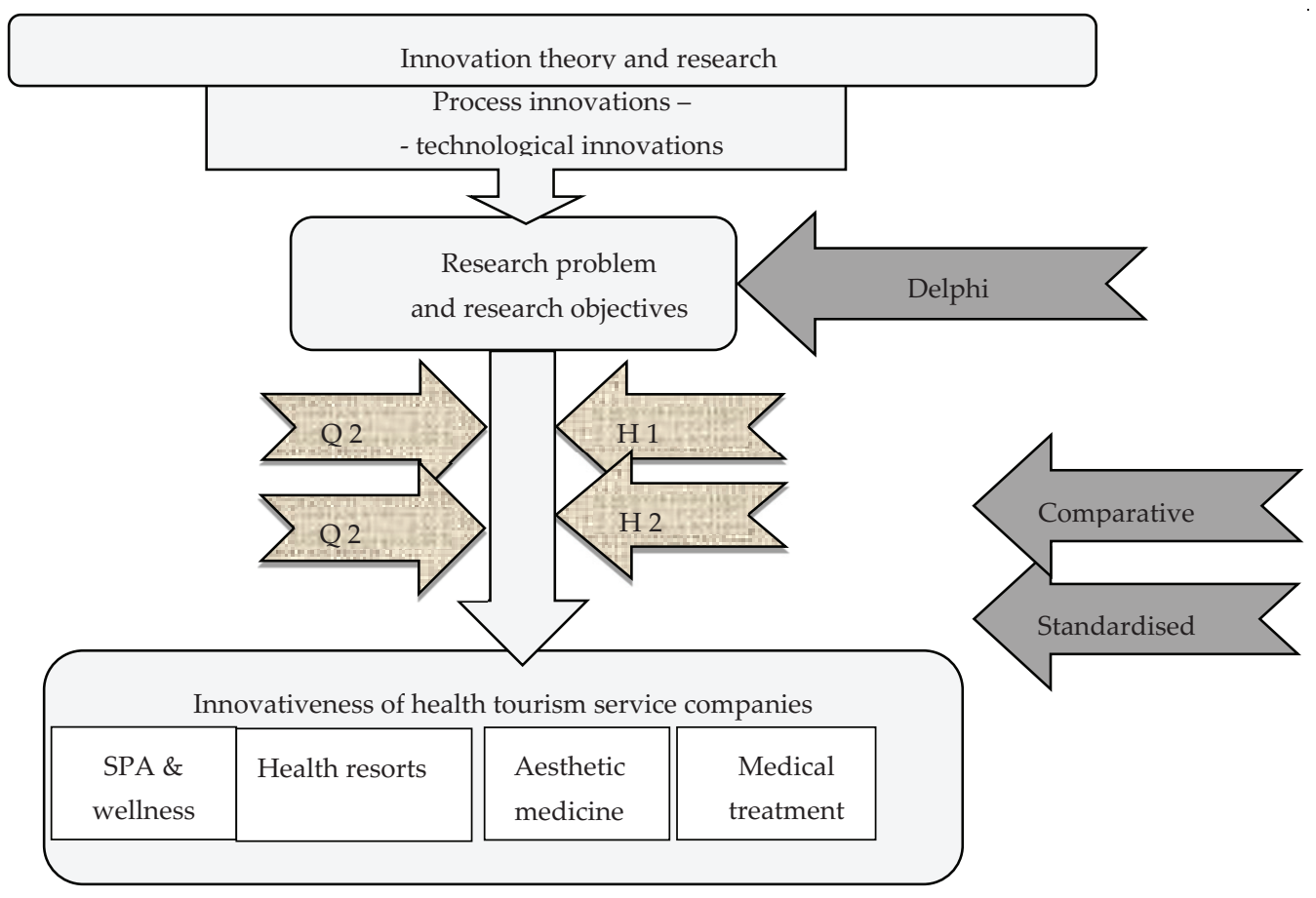

Figure 1 . The research procedure

gathering expert opinions (Vernon, 2009; Roy et al., 2014). In order to reduce this impact, the subject studies were based on the CAWI technique, which involved sending the access to the e-questionnaire by means of the Internet. Methodological assumptions presented in Table 1 satisfied the guidelines proposed by Chang-Hee Kim and Karen Yeo Beyond (2018).

Table 1. Summarised guidelines for the rigorous implementation of the Delphi Method (source: Chang-Hee Kim \& Karen Yeo, 2018, pp. 312-323)

\begin{tabular}{|l|l|}
\hline \multicolumn{1}{|c|}{ Criteria } & \multicolumn{1}{c|}{ Descriptions } \\
\hline $\begin{array}{l}\text { Clear task(s) and } \\
\text { purpose(s) }\end{array}$ & $\begin{array}{l}\text { Application of the method to a specific } \\
\text { problem }\end{array}$ \\
\hline $\begin{array}{l}\text { Selection of experts } \\
\text { and size }\end{array}$ & Qualifying panellists as experts \\
\hline $\begin{array}{l}\text { Iterative feedback } \\
\text { and consensus }\end{array}$ & $\begin{array}{l}\text { Design and administration of the } \\
\text { questionnaire }\end{array}$ \\
\hline $\begin{array}{l}\text { Pilot test of the } \\
\text { questionnaire }\end{array}$ & $\begin{array}{l}\text { Ensure reliability and reduce potential } \\
\text { bias before executing the Delphi survey }\end{array}$ \\
\hline
\end{tabular}

The leading Polish economists took part in the Delphi research. They represented disciplines of economics and management science (5 experts), in particular including economists specialising in the analysis of innovativeness and tourism economics. Moreover, survey engaged 2 tour operators - medical tourism organisers, 2 doctors and 1 manager of the health resort. The research was divided into three rounds, which corresponds with the opinions of other scientists who admit that it is recommended to use 3 to 5 rounds in the Delphi research (Lin \& Song, 2015; Custer et al., 1999). The first round comprised of pilot research. Its aim was to obtain consensus with regard to identifying entities engaged in providing health tourism services, types of innovation as well as variables affecting their technological innovativeness. These pilot studies were aimed at elaborating on the assumptions of the research concept as well as creating a survey questionnaire. The second and third rounds were used for verifying research assumptions. The Delphi electronic questionnaire (CAWI) was dispatched to 12 experts in each round. Experts taking part in each round of the research provided answers in accordance with their knowledge and regardless of other opinions. The first round was of pilot character; in the second and third rounds the subjects evaluated the significance of factors that may affect technological innovativeness in the health tourism sector. During the third round of the research, the experts were shown the results of the second round, where they could abide by their opinion or change it. The survey with the Delphi method identified a set of 53 independent variables representing five different research areas (Figure 2). In the experts' opinion, they could affect the technological innovativeness of the investigated entities.

The experts indicated factors in two different areas (internal and external) as well as 5 different categories. External factors included knowledge-based, institutional, social and market ones.

Next, the effect of the Delphi expert research was used in studying empirical entities that provide health tourism services. While identifying technological innovations in health tourism, the authors used a method of diagnostic research, its tool being semi-open multiple choice questions. The survey was conducted by means of a phone 
interview. Respondents indicated implemented innovations with regard to their division into type (organisational, product-based, marketing and technological), range (worldwide, national and regional) as well as novelty to an organisation. In order to evaluate the significance of factors affecting the implementation of technological innovations, a six-grade ( 0 to 5 ) significance scale was used, where 0 means "insignificant factor", 1 - "minor" and 5 "very significant".

Determinants of innovativeness of health tourism enterprises were distinguished based on two assumptions. The first one assumed that all the studied 53 independent variables have a different value of information carrier. The measurement was carried out by means of a multifactorial analysis of variance, using the Kruskal, Wallis test (Kruskal \& Wallis, 1952). The obtained results provided a basis for the classification of indicators supporting the technological innovativeness of providers of health tourism services which were divided into three groups (Table 2). The scale of factor variability was based on a point method. Variability sections were identified with an expert method.

Subsequently, the classified factors (supportive and complementary determinants) were analysed due to the range of the implemented innovation. The results constitute a basis for refuting or confirming the second hypothesis.

The second assumption allowed for the existence of groups of variables with similar information carriers among the identified 53 variables. A method of factor analysis was used for selecting synthetic factors that included mutually uncorrelated groups of independent variables. At a further stage of the research, variables including the largest information carrier were compared with regard to the range of the implemented innovation with the use of the Kruskal, Wallis test by ranks (Kruskal \&
Table 2. Classification of the functions of factors in the process of implementing technological innovations (source: own elaboration)

\begin{tabular}{|c|l|l|l|}
\hline Item & $\begin{array}{l}\text { Function } \\
\text { of a factor }\end{array}$ & \multicolumn{1}{|c|}{ Classification of factors } & $\begin{array}{l}\text { Weighted } \\
\text { average }\end{array}$ \\
\hline 1 & $\begin{array}{l}\text { Deter- } \\
\text { minant }\end{array}$ & $\begin{array}{l}\text { The maximum measure of } \\
\text { the central distribution }\end{array}$ & above 1.25 \\
\hline 2 & Supportive & $\begin{array}{l}\text { The measure of the central } \\
\text { distribution above the mean } \\
\text { measure of the central } \\
\text { distribution }\end{array}$ & $\begin{array}{l}\text { from } 1.24 \\
\text { to } 0.89\end{array}$ \\
\hline 3 & $\begin{array}{l}\text { Comple- } \\
\text { mentary }\end{array}$ & $\begin{array}{l}\text { The measure of the central } \\
\text { distribution varying about } \\
\text { the value of the mean } \\
\text { measure of the central } \\
\text { distribution }\end{array}$ & $\begin{array}{l}\text { from } 0.88 \\
\text { to } 0.69\end{array}$ \\
\hline
\end{tabular}

Wallis, 1952). The results provide a basis for refuting or confirming the second hypothesis. The first hypothesis was confirmed or the refuted with Spearman's rank correlation coefficient. The test involved entities that implemented radical innovations and was correlated? with the factor "openness towards tourists and their needs".

\subsection{Sample}

The examined entities were selected on the basis of the Polish Classification of Activity PKD (2014). The whole size of the examined population was described on the basis of a local data bank (2014) consisting of 241,393 entities. The size of the representative sample was calculated with the use of a calculator of the research sample. The following parameters were adopted for the calculation of the size of the examined sample: the confidence level of 0.95 , the expected fraction size of 0.5 and the maximum

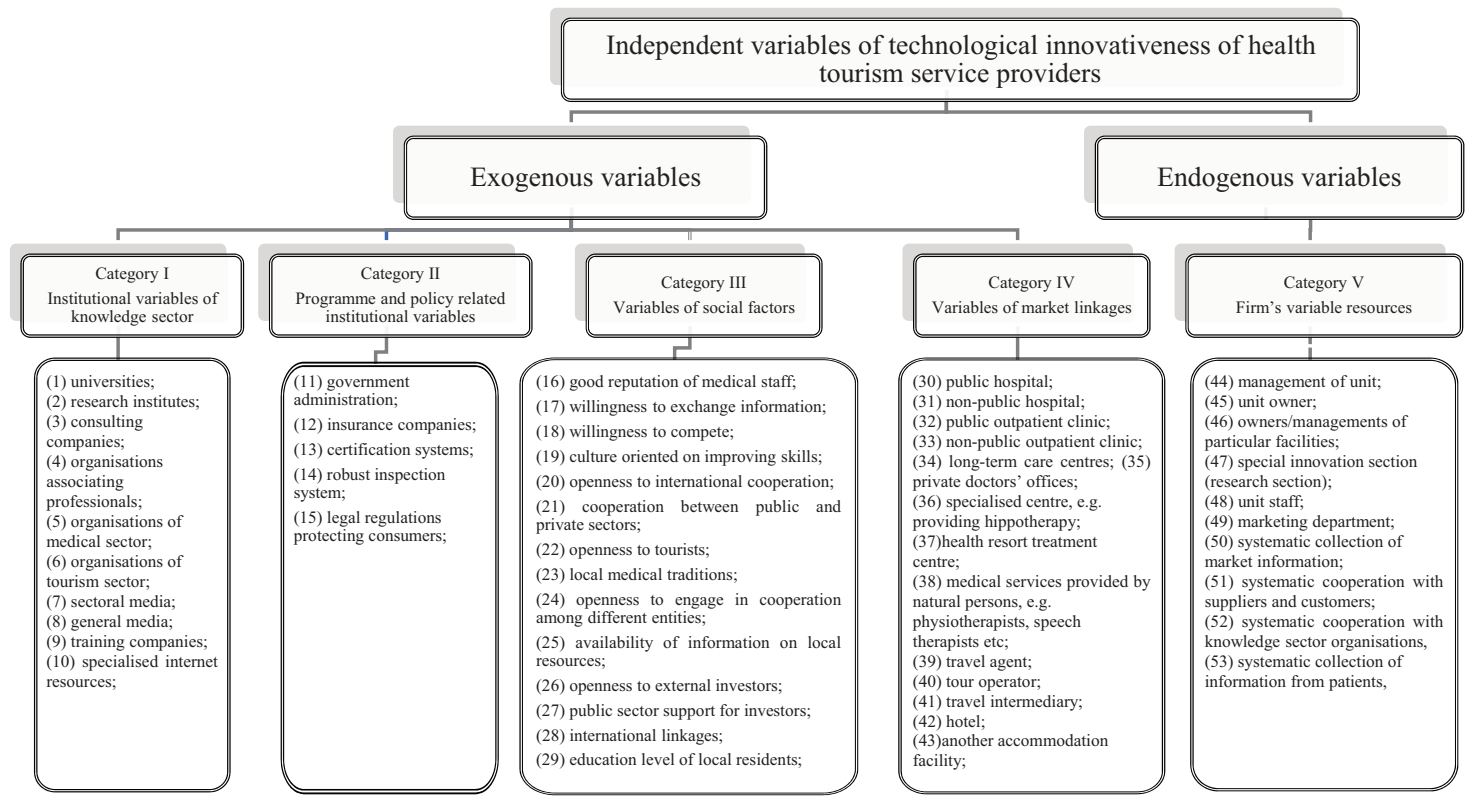

Figure 2. Independent variables which may affect the technological innovativeness of providers of health tourism services 
error of 0.05 . The minimum sample size was comprised of 384 entities. The research was conducted in the years 2015-2017. The research material was collected by means of a survey questionnaire. Three techniques were applied in collecting data: CAWI, PAPI and a telephone interview. The authors purchased 35,000 e-mail addresses and distributed a link to the questionnaire among the addresses (portal: ankietka.pl). The CAWI technique proved to be hardly effective. Ultimately, as a result of the research (with a simple random selection), questionnaires were collected from 461 entities.

The research disregarded questionnaires completed by outpatient clinics and hospitals which involved services used by local customers and fully financed by the National Health Fund (NFZ) or the Social Insurance Company (ZUS) and the questionnaires in which respondents provided services other than health tourism. As a result of negative verification, the research was carried out among 386 entities. Out of this group, the authors identified service providers which introduced technological innovations within a minimum regional range in a three-year period under study, i.e. 145 investigated entities (Figure 3).

Among the respondents, the largest group consisted of outpatient clinics, private doctors' offices, hospitals and other providers of medical services (54.48\% of the investigated entities). Accommodation facilities which offered spa and/or wellness treatments (27.59\%) as well as health resorts and health resort hospitals were much less represented $(10.34 \%)$. The smallest group consisted of providers of travel services, i.e. tour operators, travel agents and travel intermediaries (7.59\%).

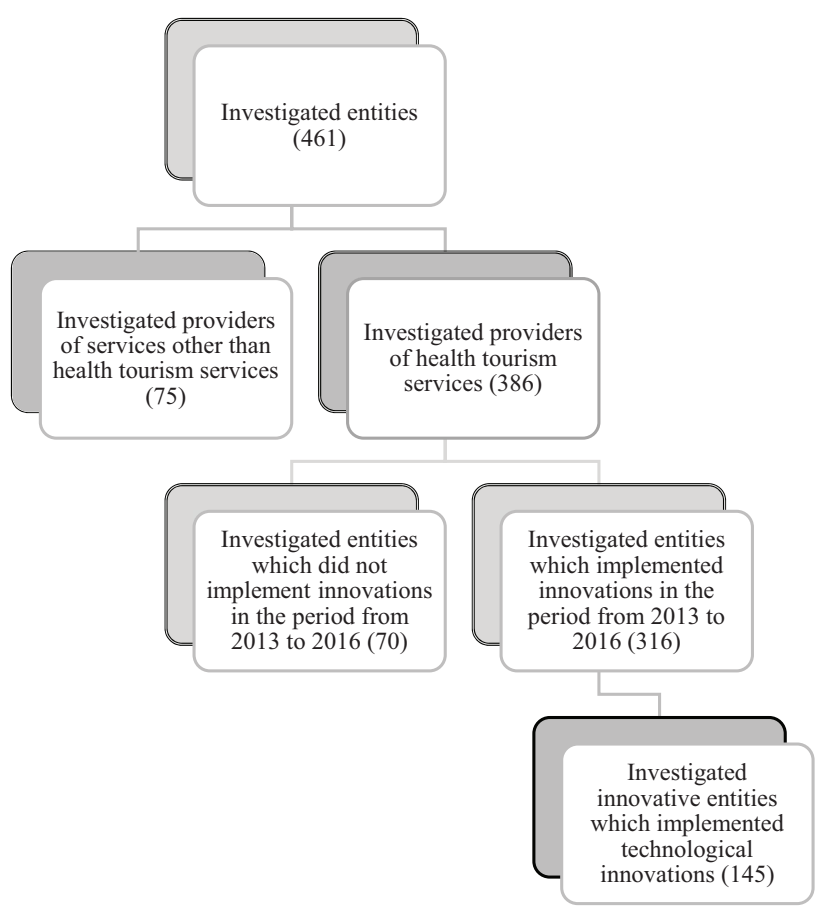

Figure 3. Structure of the research sample (source: research-based elaboration)

\section{Results analysis}

The research demonstrated that, out of 316 investigated entities which implemented innovations in the period from 2013 to 2015, 145 entities (45.89\%) implemented technological innovations, where 141 entities (44.62\%) implemented technological innovations that included new machinery and equipment, and 31 entities (9.81\%) implemented specialist software.

The analysis of research results allows for claiming that the entities, regardless of the type of conducted activity pointed to the application of new computer software, including: software dedicated to customer service, e-documentation and treatment planning. Many declared the implementation of laser appliances - the only difference consisted in the type of the implemented laser appliance, depending on the sector of provided services. Discrepancies in the type of implemented innovation with regard to the segment of rendered services appeared in case of innovative appliances. Facilities providing sanatorium services implemented, among other things: massage (e.g. lymphatic) appliance, author's system of air cleaning with the use of carbon filters, inhalators and gynaecological appliances. Facilities offering spa and wellness services pointed to the following innovations: hydro massage capsules and cardiolysis equipment. Aesthetic medicine providers introduced new gynaecological equipment for corrective treatments and a fractional laser. Entities providing medical services indicated the implementation of blood test appliances, fractional lasers and quartz lamps as technological innovations.

Innovations involving the use of new technologies (machinery and equipment) were implemented by $97.24 \%$ of service providers from the investigated group of 145 entities. Moreover, $8.97 \%$ of the investigated entities implemented innovations that involved the use of new technologies with a worldwide range. The largest

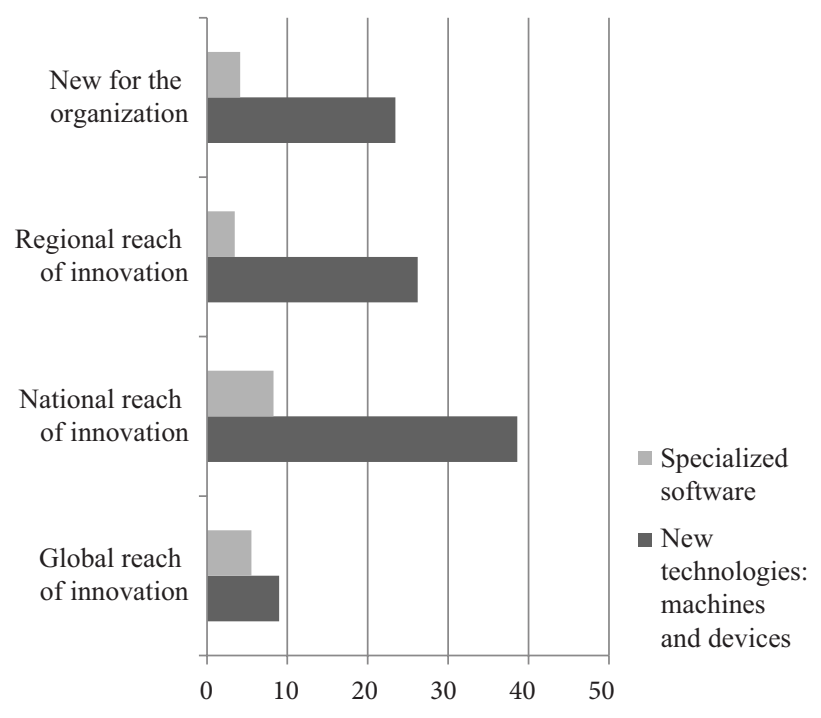

Figure 4. The range of the implemented innovations [in \%] (source: research-based own elaboration, $\mathrm{N}=145$ ) 
group, representing $38.62 \%$ of the investigated entities, implemented innovations with a national range, $26.21 \%$ those with a regional range and $23.45 \%$ of the investigated entities implemented innovations which were new to the organisation. In turn, innovations in the scope of specialist software were implemented by a much lower number of entities (21.38\%); in this scope, too, the largest number of innovations had a national range $(8.28 \%)$, whereas $5.52 \%$ of the investigated entities implemented innovations with a worldwide range (Figure 4).

As a consequence of achieving the statistical consistency of innovativeness factors in respect of the range and type of the implemented innovation, independent variables were characterised with the use of a mean value defining the measure of the central tendency of the distribution, and a standard deviation defining the measure of the mean deviation of the measurement results from the mean value.

The calculations of the results for all the factors in all five analysed categories allowed for diagnosing determinants. The most important ones turned out to be exogenous institutional variables of the knowledge sector (I). They were followed by exogenous variables related to social factors (III) and endogenous variables in a form of the company's resources $(\mathrm{V})$. Other groups of factors played a much lesser role. They included institutional, programme and policy factors (II) as well as market linkages (IV) (Figure 5).

Obtaining the results of the research led to distinguishing three significant clusters of factors affecting in different ways the technological innovativeness of health tourism. They indicated a similarity of the measure of the central tendency of the distribution and the measure of the mean deviation of the measurement results from the mean value. These clusters were plotted with ellipses in Figure 6. The most important ones were encircled with a bold ellipse, enclosing the variables considered to be determinants (Figure 6).

The group of factors with the highest significance for technological innovations included an institutional factor related to the transfer of knowledge, specifically sectoral media (7), which acquired the highest distribution measure (a weighted mean of 1.31). The respondents did not agree on its significance, as evidenced by a relatively high measure of the mean standard deviation of the measurement results from the mean value (a standard deviation

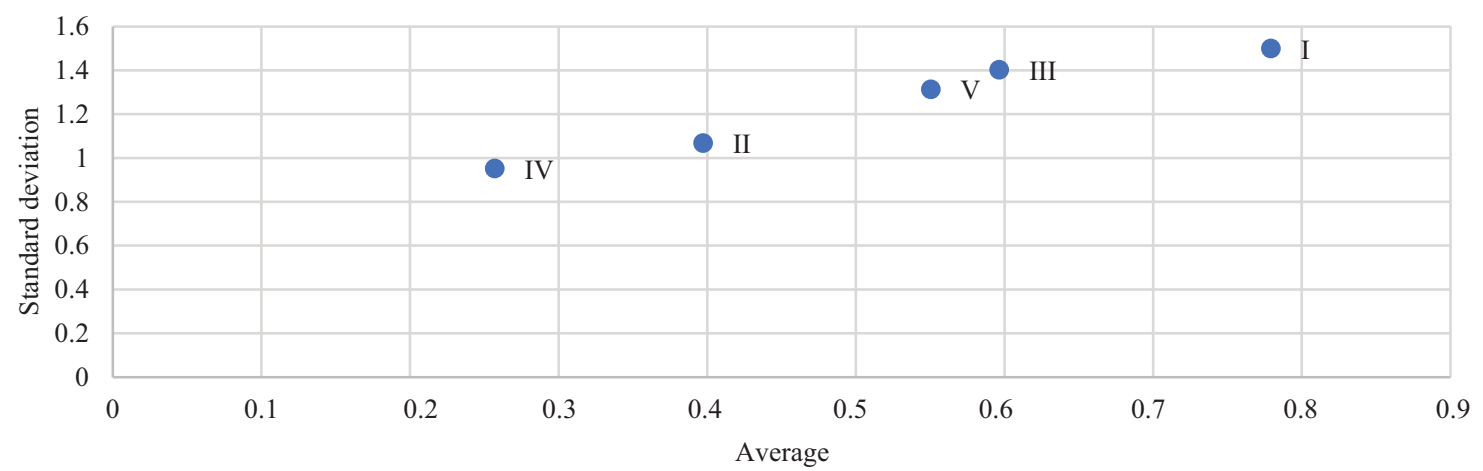

Figure 5. Categories of technological innovativeness factors (source: own elaboration based on research results with the use of the Kruskal, Wallis test [59] (583-621). Use of ranks in one - criterion variance analysis, $\mathrm{N}=145$

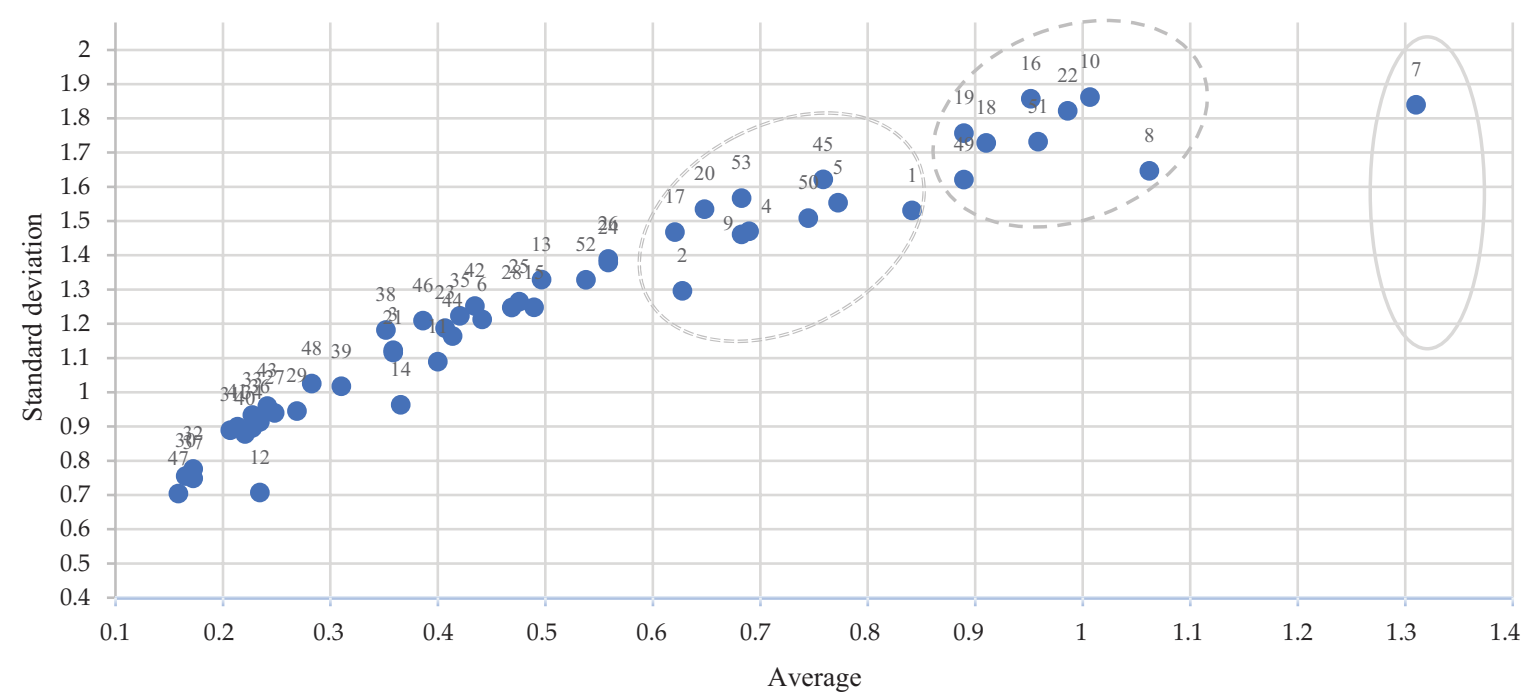

Figure 6. Indicators of the technological innovativeness of health tourism (source: own elaboration based on the research results, $\mathrm{N}=145$ ) 
of 1.8). This resulted from the fact that the investigated entities indicated both a value of 0 , i.e. "insignificant" and a value of 5, i.e. "very significant". However, a high central measure of the distribution indicated that values exceeding 0 dominated.

Another cluster marked with an ellipse encircled by a single dashed line represents a high measure of the distribution achieved and the differentiated measures of the mean deviation of the measurement results from the mean value. The factors placed inside should be classified as supportive. They were characterised by the mean measure of central distribution, reaching measures of central distribution in excess of mean results (with a weighted mean oscillating between 0.89 and 1.2), and the measure of the mean deviation of the measurement results from the mean value, which was diversified (with a standard deviation oscillating between 1.86 and 1.62). Exogenous supportive factors included:

- general media (8) and specialised Internet resources (10);

- social factors, such as: openness to tourists (22), good reputation of medical staff (16);

- willingness to compete (18);

- culture oriented on improving skills (19).

- Endogenous supportive factors with regard to the company's resources included:

- systematic cooperation with suppliers and customers (51);

- the Marketing Department (49);

- universities (1).

A third cluster of factors marked in the figure with an ellipse encircled by a double dashed line concentrated around the mean central measure of distribution and the differentiated measure of the mean deviation of the measurement results from the mean value. These factors need to be classified as complementary, i.e. their mean measure of distribution is close to the mean results of the measure of central distribution (with a weighted mean oscillating between 0.69 and 0.8 ) and the measure of the mean deviation of the measurement results from the mean value is differentiated (with a standard deviation between 1.52 and 1.21

Complementary factors should be considered to include institutional factors related to the transfer of knowledge: organisations of the medical sector (5), organisations associating professionals (4), training companies (9) and research institutes (2). Among the social factors, the investigated entities indicated: openness to international cooperation (20) and willingness to exchange information (17). In turn, endogenous complementary factors should be considered to include: unit owner (45), systematic collection of market information (50) and systematic collection of information from patients (53). The results are presented in Figure 6.

The classified factors: determinants, supportive and complementary factors were analysed with regard to the range of the implemented innovation (Table 5). A detailed analysis did not illustrate any discrepancies. This result allowed for a positive verification of the second hypothesis (H2). At the same time, it was not observed whether tourist needs and expectations measured with the "openness to tourists" factor affected undertaking radical innovative measures. The results allow for the negative verification of the first hypothesis (H1). This conclusion was confirmed with the result of Spearman's rank correlation coefficient (Table 3). Spearman's rank correlation coefficient indicated that there exists no significant dependency between implementing radical technological innovations and tourist needs and expectations.

Table 3. Statistical significance test (source: own elaboration, Statistica software)

\begin{tabular}{|c|c|c|c|c|}
\hline \multirow{2}{*}{$\begin{array}{c}\text { Pair of } \\
\text { variables }\end{array}$} & \multicolumn{3}{|c|}{ Spearman's rank correlation coefficient } \\
\cline { 2 - 5 } & $\begin{array}{c}\text { (N) Signi- } \\
\text { ficant }\end{array}$ & $\begin{array}{c}\text { (R) } \\
\text { Spearman }\end{array}$ & $\mathrm{T}(\mathrm{N}-2)$ & $\mathrm{P}^{*}$ \\
\hline $\begin{array}{l}\text { Entities imple- } \\
\text { menting radical } \\
\text { innovations / } \\
\text { openness to } \\
\text { tourists factor }\end{array}$ & 36 & 0.061021 & 0.356493 & 0.723674 \\
\hline
\end{tabular}

* The marked correlation coefficients are significant with $\mathrm{p}<0.05000$.

The factor analysis indicated that there exist groups of factors with significant impact on technological innovativeness. These five groups (of synthetic factors) accounts for $51 \%$ of changeability, where the first synthetic factor explains over $31 \%$ of changeability. Detailed results are presented in Table 4 and Table 5.

Table 4. Evaluation of innovativeness factor significance result of factor analysis (source: own elaboration, Statistica software)

\begin{tabular}{|c|c|c|c|c|}
\hline \multirow{2}{*}{ Value } & \multicolumn{4}{|c|}{ Own values, identified main components } \\
\cline { 2 - 5 } & Own value & $\begin{array}{c}\text { \% of total } \\
\text { variations }\end{array}$ & $\begin{array}{c}\text { Accumu- } \\
\text { lated own } \\
\text { value }\end{array}$ & $\begin{array}{c}\text { Accumulated } \\
\%\end{array}$ \\
\hline 1 & 16,49539 & 31,12338 & 16,49539 & 31,12338 \\
\hline 2 & 3,57462 & 6,74452 & 20,07 & 37,86795 \\
\hline 3 & 2,77513 & 5,23612 & 22,84516 & 43,10407 \\
\hline 4 & 2,21091 & 4,17162 & 25,05612 & 47,27568 \\
\hline 5 & 2,07212 & 3,90975 & 27,12828 & 51,18543 \\
\hline
\end{tabular}

The first synthetic factor included the following innovativeness factors: personnel's good reputation (16), raising qualifications (19), openness to international cooperation (20), facility owner (45) management board of specific facilities (46), and systematic data collection from patients/customers (53). This coefficient accumulated endogenic factors that should be described as "the quality of human resources in the organisation". This group disregarded the factor "openness to customers" (20). Thus, the first hypothesis (H1) was verified negatively. 
Table 5. Indicators of the technological innovativeness of health tourism with regard to range of innovation (source: own elaboration based on the research results, $\mathrm{N}=145$. A: average, $\mathrm{SD}$ : standard deviation)

\begin{tabular}{|c|c|c|c|c|c|c|c|c|c|c|c|c|c|c|c|c|c|c|c|c|}
\hline \multirow{3}{*}{ 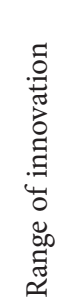 } & \multirow{3}{*}{ 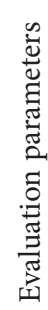 } & \multicolumn{19}{|c|}{ Innovativeness factors as per category } \\
\hline & & I & \multicolumn{8}{|c|}{ II } & \multicolumn{10}{|c|}{ III } \\
\hline & & 7 & 8 & 10 & 16 & 18 & 19 & 22 & 51 & 49 & 1 & 5 & 45 & 50 & 4 & 9 & 53 & 20 & 2 & 17 \\
\hline \multirow{2}{*}{$\begin{array}{l}\vec{\pi} \\
\tilde{\Xi} \\
0\end{array}$} & A & 1.31 & 1.06 & 1.01 & 0.95 & 0.91 & 0.89 & 0.99 & 0.96 & 0.89 & 0.84 & 0.77 & 0.76 & 0.74 & 0.69 & 0.68 & 0.68 & 0.65 & 0.63 & 0.62 \\
\hline & SD & 1.84 & 1.65 & 1.86 & 1.86 & 1.73 & 1.76 & 1.82 & 1.73 & 1.62 & 1.53 & 1.55 & 1.62 & 1.51 & 1.47 & 1.46 & 1.57 & 1.53 & 1.30 & 1.47 \\
\hline \multirow{2}{*}{$\frac{\dot{\vec{Z}}}{3} \frac{\overrightarrow{0}}{3}$} & A & 1.25 & 1.05 & 0.91 & 0.76 & 0.80 & 0.62 & 0.77 & 0.83 & 0.75 & 0.59 & 0.64 & 0.54 & 0.54 & 0.64 & 0.54 & 0.44 & 0.51 & 0.50 & 0.42 \\
\hline & SD & 1.83 & 1.67 & 1.84 & 1.70 & 1.69 & 1.53 & 1.71 & 1.65 & 1.50 & 1.29 & 1.45 & 1.39 & 1.28 & 1.41 & 1.37 & 1.22 & 1.41 & 1.13 & 1.23 \\
\hline \multirow{2}{*}{ 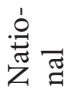 } & A & 1.29 & 1.03 & 1.01 & 0.93 & 0.90 & 0.87 & 0.97 & 0.94 & 0.87 & 0.82 & 0.76 & 0.74 & 0.73 & 0.66 & 0.67 & 0.66 & 0.63 & 0.62 & 0.61 \\
\hline & SD & 1.85 & 1.63 & 1.87 & 1.84 & 1.73 & 1.75 & 1.82 & 1.72 & 1.61 & 1.50 & 1.55 & 1.61 & 1.49 & 1.43 & 1.46 & 1.55 & 1.52 & 1.29 & 1.46 \\
\hline \multirow{2}{*}{ 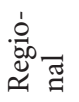 } & A & 1.31 & 1.06 & 1.01 & 0.95 & 0.91 & 0.89 & 0.99 & 0.96 & 0.89 & 0.84 & 0.77 & 0.76 & 0.74 & 0.69 & 0.68 & 0.68 & 0.65 & 0.63 & 0.62 \\
\hline & SD & 1.84 & 1.65 & 1.86 & 1.86 & 1.73 & 1.76 & 1.82 & 1.73 & 1.62 & 1.53 & 1.55 & 1.62 & 1.51 & 1.47 & 1.46 & 1.57 & 1.53 & 1.30 & 1.47 \\
\hline \multirow{2}{*}{ 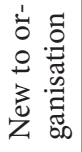 } & A & 1.27 & 0.99 & 0.96 & 0.88 & 0.86 & 0.84 & 0.98 & 0.89 & 0.86 & 0.81 & 0.70 & 0.68 & 0.66 & 0.65 & 0.65 & 0.61 & 0.58 & 0.59 & 0.58 \\
\hline & SD & 1.84 & 1.61 & 1.84 & 1.79 & 1.71 & 1.72 & 1.83 & 1.67 & 1.60 & 1.49 & 1.51 & 1.56 & 1.42 & 1.43 & 1.44 & 1.48 & 1.46 & 1.25 & 1.44 \\
\hline
\end{tabular}

The first synthetic factor included the following innovativeness factors: personnel's good. These factors were compared with regard to the range of innovation (with worldwide, national, regional range as well as being new to organisation) with the use of the Kruskal, Wallis - test by ranks. There appeared no statistically significant differences between specific factors for various ranges of innovation (Table 6). Therefore, the second hypothesis was positively verified.

Table 6. Statistical significance test (source: elaboration based on Statistica software)

\begin{tabular}{|c|c|c|}
\hline Factor number & $\begin{array}{c}\text { H - statistics } \\
\text { of the Kruskal, } \\
\text { Wallis - test }\end{array}$ & $\begin{array}{c}\text { p- test } \\
\text { probability* }\end{array}$ \\
\hline 16 & 0.696 & 0.874 \\
\hline 19 & 1.448 & 0.694 \\
\hline 20 & 0.761 & 0.859 \\
\hline 45 & 0.152 & 0.985 \\
\hline 46 & 7.796 & 0.051 \\
\hline 53 & 3.945 & 0.268 \\
\hline
\end{tabular}

* The marked correlation coefficients are significant with $\mathrm{p}<0.05000$.

The both assumed research techniques allowed for identifying determinants of technological innovativeness of entities providing health tourism services. On the one hand, the determinant with the greatest significance is "external inflow of information". In this case it was recognised that sectoral media have the largest impact on undertaking innovative measures. The second, most significant determinant is the "quality of the unit's (organisation's) human resources".

\section{Discussion}

The results obtained in the course of the present research indicate that technological innovations were implemented by $31 \%$ of the investigated entities and that they represented $40 \%$ of innovators. These results can be compared with those of the research done by Szymańska 2009 on a group of 215 tourist companies which indicated that $28 \%$ of respondents implemented technological innovations over a three-year period. In the light of this, it can be concluded that providers of health tourism services are slightly more innovative than the average tourist companies (those running hotels and providing transport as well as travel agencies), although the difference is barely $3 \%$.

The most significant factors of technological innovations in health tourism services include institutional factors related to the transfer of knowledge, in particular two synthetic factors (determinants): external inflow of information and the quality of human resources at the organisation. This is consistent with the research results obtained by Szymańska (2009), who demonstrated that the introduction of technological innovations was related to training courses, since in the group of hotels that used this form of innovation all the enterprises trained their staff. This issue seems all the more important as, in the opinion of Pender and Sharpley, accommodation services are the most poorly computerised segment of the global tourism sector. 
The research by Szymańska indicated that each type of innovation (including product, process, organisational and technological innovations) is stimulated by other exogenous factors. In creating technological innovations, the most important factors include (Szymańska, 2009): professional literature, customers' opinions and the cooperation with universities and nongovernmental organisations. For health tourism entities that implemented technological innovations different results were obtained. Due to the range of the implemented innovation, the stimulating factors were similar.

The obtained results provide evidence of the specifics of the health tourism sector under study, whose level of innovativeness is higher than the average level of tourism enterprises, although the most significant factors that stimulate innovativeness fall in the area of knowledge. It is worth mentioning that the customers of this sector have no impact on the implemented innovations, which should be negatively evaluated.

\section{Conclusions}

The research which was carried out by Authors, made it possible to achieve the main goal and detailed objectives. The research diagnosed the determinants of technological innovativeness of health tourism enterprises which were indicated by the providers of health tourism services; specifically, the most important variable contributing to this innovativeness was the institutional factor related to the transfer of knowledge. This function was played by sectoral media. Sectoral media were a determinant in respect of both the range and type of the implemented technological innovations. Thus, the first hypothesis (H1), providing for the greatest impact of customers (tourists) was refuted. The factor of systematic collection of information from patients was classified as one of the nine complementary factors. In contrast, the second hypothesis (H2) was positively verified, since the determinants of technological innovativeness did not show differences in respect of the range of innovations and they were the same as, or very close to, both national and regional radical innovations.

The empirical research also provided answers to the posed research questions about the level of technological innovativeness of health tourism enterprises (Q1), which turned out to be slightly higher than the average level of innovativeness of tourism enterprises. In response to the other research question (2), factors with a supportive and complementary character were diagnosed and classified. The supportive factors included institutional factors from the knowledge transfer sector, i.e. general media, specialist Internet resources and universities; social factors, i.e. openness to tourists, good reputation of medical staff, willingness to compete, culture oriented on improving skills, as well as endogenous factors related to the company's resources: systematic cooperation with suppliers and customers and the Marketing Department. All the factors which the experts diagnosed in the course of the Delphi survey (Grisham, 2009) are presented in a graphic form.
The research is novel in character. Until now, technological innovations in health tourism have not been described. The dynamically developing health tourism proves a large need for this type of services; on the other hand, there is a lack of scientific research in this area with regard to economy and management. The unique character of the discussed issues is demonstrated by assumptions (hypotheses) that have a pioneering character ( $\mathrm{H} 2)$ or have been confirmed in research relating to tourism enterprises, however, in the case of entities providing health tourism services have not been confirmed (H1).

The character of the empirical research is interdisciplinary and covers two areas: medicine and tourism economy. The results have an impact on the development of economics and management sciences. The contribution to economics, in particular theory of innovation, is formulating factors that affect companies' innovativeness. The contribution to management sciences, in turn, is identifying innovativeness determinants of entities providing health tourism services. Recommendations for further research that should gain more insight with regard to specific types of health tourism services should also be highlighted. The obtained results should be implemented in studying technological innovativeness of other service providers. These results potentially contribute to the practical aspect by means of their application by practitioners - health tourism organisers, who may use them while applying technological innovations.

\section{Funding}

This work was supported by the National Science Centre granted on the basis of the decision No. DEC-2013/11/B/ HS4/02138.

\section{Author contributions}

It is estimated that each of the authors contributed 50\% to the preparation of the article. The Abstract and Introduction were written by ES. EP was responsible for data interpretation. Discussion, Conclusion and the literature review were prepared by EP and ES.

\section{Disclosure statement}

The authors declare no conflict of interest.

\section{References}

Amodeo, J. (2010). Medical refugees and the future of health tourism. World Medical \& Health Policy 2(2), 65-81. https://doi.org/10.2202/1948-4682.1103

Andreeva, N. (2014). Turystyka zdrowotne jako współczesny trend rozwojowy (Health tourism as a contemporary development trend). In J. Snarski \& M. Jalinik (Ed.), Przedsiębiorczość $w$ turystyce [Entrepreneurship in tourism] (pp. 130-138). Wydawnictwo EkoPress.

Balezentis, A., \& Balkiene, K. (2014). Innovation policy measurement: analysis of Lithuania's case. Economic ResearchEkonomska Istraživanja, 27, 1-14. https://doi.org/10.1080/1331677X.2014.947103 
Bank Danych Lokalnych (Local Data Bank). (2014). https://bdl.stat.gov.pl/BDL

Banyte, J., \& Salickaite, R. (2008). Successful diffusion and adoption of innovation as a means to increase competitiveness of enterprises. Inzinerine Ekonomika-Engineering Economics, 1(56), 48-56.

Barhoum, H., \& Djaouahdou, R. (2017). The innovation influence on small and medium-size enterprises - the Algerian case. Valahian Journal of Economic Studies, 8(22), 13-20.

Chang, S., Pu, Ch. Y, \& Hsish, P. J. (2014). A regional competition analysis of medical tourism industry an example of Taiwan. International Journal of Information and Management Sciences, 25(2), 139-156.

Chang-Hee, K., \& Karen, Y. (2018). Beyond consensus: a review of Delphi research published in Malaysian Social Science Journals. International Journal of Business and Society, 19(2), 312-323.

Chuang, T. C., Liu, J. S., Lu, L. Y. Y., \& Lee, Y. (2014). The main paths of medical tourism: from transplantation to beautification. Tourism Management, 45, 49-58.

https://doi.org/10.1016/j.tourman.2014.03.016

Ciburiene, J. (2009). The Innovativeness of SME activity in the context of globalization in Lithuania. Economics and Management, 14, 723-730.

Cormany, D., \& Baloglu, S. (2010). Medical travel facilitator websites: An exploratory study of web page contents and services offered to the prospective medical tourist. Tourism Management, 32, 709-716. https://doi.org/10.1016/j.tourman.2010.02.008

Custer, R. L., Scarcella, J. A., \& Stewart, B. R. (1999). The modified Delphi technique: A rotational modification. Journal of Vocational and Technical Education, 15(2), 1-10. https://doi.org/10.21061/jcte.v15i2.702

Dalkey, N., \& Helmer, O. (1963). An application of the Delphi method to the use of experts. Management Science, 9(3), 458467. https://doi.org/10.1287/mnsc.9.3.458

Drucker, P. F. (2004). Natchnienie i fart, czyli innowacja i przedsiębiorczość. Wydawnictwo Studio EMKA.

Dziedzic, E. (2011). Perspektywy turystyki w warunkach rozwoju opartego o innowacje [Prospects for tourism in the conditions of development based on innovation]. In E. Dziedzic (Ed.), Turystyka wobec nowych zjawisk $w$ gospodarce światowej [Tourism in the face of new developments in the global economy] (pp. 403-440). Oficyna Wydawnicza Szkoła Główna Handlowa w Warszawie [Publishing House of Warsaw School of Economics].

Ejdys, J., Ustinovičius, L., \& Stankevičienė, J. (2015). Innovative application of contemporary management methods in a knowledge-based economy - interdisciplinarity in science. Journal of Business Economics and Management, 16, 261-274. https://doi.org/10.3846/16111699.2014.986192

Flynn, S. I. (2013). Technological innovation. Research Starters: Business.

Gault, F. (2010) Innovation strategies for a global economy. Edward Elgar. https://doi.org/10.4337/9781849806725

Grisham, T. (2009). The Delphi technique: a method for testing complex and multifaceted topics. International Journal of Managing Projects in Business, 2(1), 112-130. https://doi.org/10.1108/17538370910930545

Grupp, H., Mogee, M. E. (2004). Indicators for national science and technology policy: how robust are composite indicators? Research Policy, 33(9), 1373-1384.

https://doi.org/10.1016/j.respol.2004.09.007
Halicka, K. (2016). Innovative classification of methods of the future-oriented technology analysis. Technological and Economic Development of Economy, 22(4), 574-597.

https://doi.org/10.3846/20294913.2016.1197164

Hall, C. M., \& Williams, A. M. (2008). Tourism and innovation. Routledge. https://doi.org/10.4324/9780203938430

Hazarika, I. (2010). Medical tourism: its potential impact on the health workforce and health systems in India. Health Policy and Planning, 25, 248-251. https://doi.org/10.1093/heapol/czp050

Heung, V. C. S., Kucukusta, D., \& Song, H. A. (2010). Conceptual model of medical tourism. Journal of Travel and Tourism Marketing, 27(3), 236-251.

https://doi.org/10.1080/10548401003744677

Hjalager, A. M. (2009). Innovations in travel medicine and the progress of tourism - selected narratives. Technovation, 29, 596-601. https://doi.org/10.1016/j.technovation.2009.05.012

Hjalager, A. M. (2002). Repairing innovation defectiveness in tourism. Tourism Management, 23, 465-474. https://doi.org/10.1016/S0261-5177(02)00013-4

Hjalager, A. M. (2010). A review of innovation research in tourism. Tourism Management, 31, 1-12. https://doi.org/10.1016/j.tourman.2009.08.012

Janasz, W., \& Kozioł, K. (2007). Determinanty działalności innowacyjnej przedsiębiorstw [Determinants of innovative activity of enterprises]. PWE.

Kruskal, W. H., \& Wallis, W. A. (1952). Use of ranks in one criterion variance analysis. Journal of the American Statistical Association, 47, 583-621. https://doi.org/10.1080/01621459.1952.10483441

Lee, H. K., \& Fernando, Y. (2015). The antecedents and outcomes of the medical tourism supply chain. Tourism Management, 46, 148-157. https://doi.org/10.1016/j.tourman.2014.06.014

Lin, V. S., \& Song, H. (2015). A review of Delphi forecasting research in tourism. Current Issues in Tourism, 18(12), 10991131. https://doi.org/10.1080/13683500.2014.967187

Lunt, N., \& Carrera, P. (2010). Medical tourism: assessing the evidence on treatment abroad. Maturitas, 66, 27-32. https://doi.org/10.1016/j.maturitas.2010.01.017

Morgan, J. Q. (2010). Governance. Policy innovation, and local economic development in North Carolina. Policy Studies Journal, 38, 679-702. https://doi.org/10.1111/j.1541-0072.2010.00379.x

Nazarko, Ł. (2016). Responsible research of innovation - new paradigm of technology management. Business and Management - Conference Proceedings. Vilnius Gediminas Technical University. https://doi.org/10.3846/bm.2016.71

OECD. (2005). Oslo manual: Guidelines for collecting and interpreting innovation data. OECD and Eurostat. https://doi.org/10.1787/9789264013100-en

OECD. (2006). Innovation and growth in tourism. OECD and Eurostat. https://doi.org/10.1787/9789264025028-en

OECD. (2008). Oslo manual. OECD and Eurostat.

Palos-Sanchez, P., Sura, J., \& Reyes-Menendez, A. (2018). Users acceptance of location-based marketing apps in tourism sector: an exploratory analysis. Journal of Spatial and Organizational Dynamics, 6(3), 258-270.

Panfiluk, E. (2016). Aesthetic medicine tourism - nature and scope of services. Ekonomia i Zarzadzanie, 8, 71-79. https://doi.org/10.1515/emj-2016-0008

Perunovic, Z., \& Christiansen, T. B. (2005). Exploring Danish innovative manufacturing performance. Technovation, 26, 10511058. https://doi.org/10.1016/j.technovation.2004.02.013

Polska Klasyfikacja Działalności [Polish Classification of Activities]. (2014). http://www.pkd.com.pl/wyszukiwarka/lista_pkd 
Rosenberg, N., \& Schumpeter, J. (1994). Radical economist. In Exploring the black box. Technology, economics, and history. Cambridge University Press. https://doi.org/10.1017/CBO9780511582554.005

Roy, R., Chan, N. W., \& Ahmed, Q. N. (2014). A Delphi study to determine sustainability factors: The case of rice farming in Bangladesh. Journal of Sustainability Science and Management, 9(1), 56-68. https://doi.org/10.1007/s11625-013-0234-4

Rycroft, R. W. (2003). Technology-based globalization indicators, centrality of innovation network data. Technology in Society, 25, 299-317. https://doi.org/10.1016/S0160-791X(03)00047-2

Schumpeter, J. (1960). Teoria rozwoju gospodarczego [The Theory of Economic Development]. PWN.

Stepaniuk, K. (2012). Portal społecznościowy w kreowaniu potrzeb turystycznych [Social networking in creating travel needs]. Zeszyty Naukowe Uniwersytetu Szczecińskiego. Ekonomiczne Problemy Ustug, 83, 45-56.

$\mathrm{Su}$, Ch.-m. (2018). A study of policies for improving the technological innovation capacity of small and medium-sized enterprises. TEM Journal, 7(2), 268-280.

Sundbo, J., Orfila-Sintes, F., \& Sorensen, F. (2007). The innovative behavior of tourism firms - Denmark and Spain. Reserch Policy, 36, 88-106. https://doi.org/10.1016/j.respol.2006.08.004

Szymańska, E. (2013). Procesy innowacyjne przedsiębiorstw świadczacych ustugi $w$ zakresie organizacji imprez turystycznych [Innovation processes at providers of services related to the organisation of tourist events - in Polish]. Publishing House of the Bialystok University of Technology.

Szymańska, E. (2009). Innowacyjność przedsiębiorstw turystycznych $w$ Polsce [Innovativeness of tourist companies in Poland - in Polish]. Publishing House of the Bialystok University of Technology.
Szymańska, E. (2016, on-line 2017). Consumer participation in the health tourism innovation proces. Economics and Management, 8(4), 28-38. https://doi.org/10.1515/emj-2016-0030

Szymańska, E., Dziedzic, E., Panasiuk, A. M., Panfiluk, E., \& Rutkowski, A. (2017). Innowacje $w$ turystyce zdrowotnej [Health tourism innovations]. Wydawnictwo DIFIN.

Teece, D. J. (1997). Capturing value from technological innovation: innovation, strategic partnering, and licensing decisions. In M. L. Thusman \& P. Anderson (Ed.), Managing strategic innovation and change. Oxford University Press.

Tuominen, M., Rajala, A., \& Möller, K. (2004). How does adaptability drive firm innovativeness. Journal of Business Research, 57, 495-506. https://doi.org/10.1016/S0148-2963(02)00316-8

Urban, W., \& Czerska, J. (2016). Reaching an entrepreneurial management system of amoebas. A qualitative insight into the European experiences. Ekonomia i Zarzadzanie, 8, 7-18. https://doi.org/10.1515/emj-2016-0001

Vernon, W. (2009). The Delphi technique: A review. International Journal of Therapy and Rehabilitation, 16(2), 69-76. https://doi.org/10.12968/ijtr.2009.16.2.38892

Webber, R. A. (1996). Zasady zarządzania innowacjami. PWE.

World Health Organization. (2017). http://www.who.int/about/ definition/en/print.html

Zorska, A. (2007). Korporacje transnarodowe. Przemiany, oddziaływania, wyzwania [Trasnational Corporations. Change, Impact, Challenges]. PWN. 